\title{
Criminal Law Aspects of Forcibly Taking the Corpse of Suspect/Probable COVID-19 Patients in Hospitals
}

\author{
Mafidhatul Laely $^{1}$, Hestiningtyas Sri Pudjaningrum ${ }^{1}$, Lelyana Susi Anggraini ${ }^{1}$, Asmuni ${ }^{2}$, Sutarno $^{2}$ \\ ${ }^{1}$ Students of Master of Law at Hang Tuah University, Surabaya, Indonesia, ${ }^{2}$ Assistant Professor, Faculty of Law, \\ Hang Tuah University, Surabaya Indonesia
}

\begin{abstract}
The purpose of this study is to find out the Criminal Law aspects of forcibly taking the corpse of suspect/ probable Covid-19 patients in Hospitals. Efforts to forcibly taking the corpse of suspect/probable Covid-19 patients by family continue to occur in a number of areas, often by mobilizing masses. Hundreds of people came to the hospital to forcibly taking the corpse of Covid-19 patients who had just died. There are so many cases of forcibly taking the corpse of suspect/probable Covid-19 patients that have occurred in Indonesia, but no legal action has been taken by law enforcement officials to take action against and detain the perpetrators of forcibly taking the corpse of suspect/probable Covid-19 patients. This caused the absence of legal certainty, both legal protections for the Hospital and for the patient's family.
\end{abstract}

Keywords: Criminal law aspects, forced taking, corpse of suspect/probable Covid-19 patients

\section{Introduction}

The World Health Organization (WHO) determined the status of Corona Virus Disease 2019 (Covid-19) as a Pandemic on March $11^{\text {th }}, 2020$ at the WHO office, Geneva, Switzerland. The latest data announced by WHO as of March $8^{\text {th }}, 2020$, the number of cases globally there were 105,586 confirmed cases, in China 80,859 confirmed with 3,100 deaths. For areas outside China there were 24,727 confirmations and 484 deaths spread across 101 countries. On December 31 $1^{\text {st }}, 2019$, WHO China Country Office reported a case of pneumonia of unknown etiology in Wuhan City, Hubei Province, China. Corona viruses are a large family of viruses that cause illness ranging from mild to severe symptoms. There are at least two types of coronavirus that are known to cause illnesses that can cause severe symptoms

\section{Corresponding Author:}

Mafidhatul Laely

Student Magister, Faculty of Law, Hang Tuah

University, Indonesia

contact : Telp +6285331717020

E Mail: dr.fidhasutikno.lmg@gmail.com such as Middle East Respiratory Syndrome (MERS) and Severe Acute Respiratory Syndrome (SARS) ${ }^{1}$.

The families of Suspect/Probable Covid-19 patients often doubt the corpse management procedure of Covid-19 PDP patients is in accordance with religious law (Islam). It makes the families of Suspect/Probable Covid-19 Patients often want the corpse management of Suspect/Probable Covid-19 patients to be done alone, where the corpse management of Suspect/Probable Covid-19 by the family will endanger the people who carry out the corpse management. There is still the Covid-19 virus attached to the corpse, which is basically the same in all other infectious diseases.

There have been so many cases of forcibly taking the corpse of Suspect/Probable Covid-19 patients that have occurred in Indonesia, but not a single legal action has been taken by law enforcement officials to take action against and detain the perpetrators of forcibly taking the corpse of Suspect/Probable Covid-19 patients. This caused the absence of legal certainty, both legal protections for the hospital and for the patient's family. 


\section{Discussion}

\section{Covid-19}

Coronavirus Disease 2019 (COVID-19) is an infectious disease caused by Severe Acute Respiratory Syndrome Coronavirus 2 (SARS-CoV-2). SARS$\mathrm{CoV}-2$ is a new type of coronavirus that has never been previously identified in humans. There are at least two types of coronavirus that are known to cause diseases that can cause severe symptoms such as Middle East Respiratory Syndrome (MERS) and Severe Acute Respiratory Syndrome (SARS). Common signs and symptoms of COVID-19 infection include acute respiratory symptoms such as fever, cough and shortness of breath. The average incubation period is 5-6 days with the longest incubation period of 14 days. Severe cases of COVID-19 can cause pneumonia, acute respiratory syndrome, kidney failure and even death.

The cause of COVID-19 is a virus that classified to the coronavirus family. Coronavirus is a positive singlestranded RNA virus, encapsulated and unsegmented. There are 4 main protein structures in Coronavirus, namely: protein $\mathrm{N}$ (nucleocapsid), glycoprotein $\mathrm{M}$ (membrane), spike glycoprotein $\mathrm{S}$ (spike), protein $\mathrm{E}$ (sheath). Coronavirus classifies to the order Nidovirales, Coronaviridae family. This coronavirus can cause disease in animals or humans. There are 4 genus, namely alphacoronavirus, betacoronavirus, gammacoronavirus, and deltacoronavirus. Before COVID-19, there were 6 types of coronavirus that could infect humans, namely HCoV-229E (alphacoronavirus), HcoV OC43 (betacoronavirus), HCoVNL63 (alphacoronavirus) HCoV-HKU1 (betacoronavirus), SARS-CoV (betacoronavirus), and MERS- CoV (betacoronavirus).

The operational definition of the division of the Covid-19 patient group

a. Suspect Case, A person who has one of the following criteria:

People with Acute Respiratory Infections (ARI) and in the last 14 days before symptoms appeared had a history of travel or live in countries/regions of Indonesia that report local transmission.
People with one of the symptoms/signs of ARI and in the last 14 days before symptoms appeared had a history of contact with a confirmed/probable COVID-19 case. People with severe ARI/severe pneumonia requiring hospital treatment and no other cause based on a convincing clinical description.

\section{b. Probable Case}

Suspect cases with severe ARD/ARDS/died with a convincing clinical description of COVID-19 and no RT-PCR laboratory examination results.

If you find a probable case, public health management will be carried out including:

a. Isolation of probable cases is carried out as long as the isolation is not completed in accordance with the discussion in clinical management

b. Monitoring of probable cases is carried out periodically as long as isolation has not been declared. Monitoring is carried out by FKRTL officers. If you have finished it, isolation/monitoring can be given a letter

c. If a probable case dies, the corpse management is in accordance with the protocol for corpse management for the confirmed COVID-19 case.

d. Epidemiological investigation. Epidemiological investigation is still carried out mainly to identify close contacts.

\section{e. Risk communication}

Health workers provide risk communication to close contact cases in the form of information about COVID-19, prevention of transmission, monitoring the development of symptoms, and others.

Patients with Suspect or Probable status who are suspected as Covid-19 with the criteria of mild illness, moderate illness, severe illness or critical conditions are treated like patients confirmed as Covid-19 until proven not Covid-19.

\section{Corpse of Suspect/Probable Covid-19 Patient}

Biologically, death is the cessation of activity in the biological body of an individual which is marked by loss 
of brain function, cessation of heartbeat, cessation of blood pressure and cessation of the respiratory process.

Death can be divided into two phases, namely: somatic death and biological death. Somatic death is a phase of death where there are no signs of life anymore, such as heart rate and breathing movements, decreased body temperature, and no brain electrical activity on the EEG record. After two hours, somatic death will be followed by biological death marked by cell death.

Pandemic condition resulted in many deaths and it cannot be determined with certainty whether the corpse or death is died because of Covid-19. This requires specific management steps to prevent the occurrence of spread to medical and corpse management personnel, as well as to families and the general public.

The corpses of patients with COVID-19 need to be managed ethically and properly in accordance with religion, values, norms and culture. The main principle in providing this service is that all officers are required to carry out standard precautions and be supported by adequate infrastructure. Criteria for the corpse of patient:

Suspected corpse from inside the hospital before the result of the swab is released.

The corpse of patient from inside the hospital that has been determined as a probable/confirmed case of COVID-19.

A corpse from outside the hospital, with a history that meets the probable/confirmation criteria for COVID-19. This includes DOA (Death on Arrival) patients referred from other hospitals ${ }^{2}$.

\section{Hospital}

A hospital is one type of health service facility, whose main task is to serve individual health in addition to other service tasks. The definition of a hospital is formulated in Article 1 point 1 of the Law concerning Hospitals that: "A hospital is a health service facility that organizing health services providing inpatient, outpatient and emergency services"

Law of the Republic of Indonesia Number 44 of 2009 Article 24 states that in the Organization of tiered health services and referral functions, General Hospitals and Special Hospitals are classified based on the facilities and capabilities of Hospital services. The General Hospitals classification consists of:
a. Type A hospital
b. Type B hospital
c. Type C hospital
d. Type D hospital

Hospital as an organization of business entities in the health sector has an important role in realizing the optimal degree of public health ${ }^{3}$. Article 1 Paragraph 1 of the Hospital Law explains that a hospital is a health service institution that organizing complete individual health services that provide inpatient, outpatient and emergency services. The hospital is a work place for professionals who carry out their activities based on their oath pronunciation and professional code of ethics. Therefore, hospitals are required to be able to manage their activities, by prioritizing the responsibilities of professionals in the health sector, especially medical and nursing personnel in carrying out their duties and authorities.

Hospital as one of the health service facilities is part of health resources which are indispensable in supporting the organization of health efforts. The organization of health services in hospitals has very complex characteristics and organizations. The statutory regulations that are used as the basis for the organization of hospitals, namely Law Number 44 of 2009 concerning Hospital. The existence of this law is intended to provide legal certainty and protection to improve, direct and provide a basis for hospital management ${ }^{4}$.

Infection Prevention and Control for Corpse Management of Covid-19 patients need to be managed ethically and properly in accordance with religion, values, norms and culture. The main principle in providing this service is that all officers are required to carry out standard precautions and be supported by adequate infrastructure. Criteria for corpse of patient:

1. Corpse of the suspect from inside the hospital before the result of the swab is released. 
2. Corpse of patient from inside the hospital that has been determined as a probable/confirmed case of Covid-19

3. A corpse from outside the hospital, with a history that meets the probable/confirmation criteria of Covid-19. This includes DOA (Death on Arrival) patients referred from other hospitals.

Precautions when receiving corpse from rooms with suspected/probable/confirmed (+) Covid-19 cases include:

1. Using appropriate PPE during contact with the corpse.

2. Hand hygiene before and after contact with the corpse.

3. Decontamination of the environment, including all surfaces of objects and tools with disinfectants.

4. Precautions for transmission should be carried out against procedures that generate aerosols.

5. Prepare plastic wraps or corpse bags that are watertight for transferring the corpse.

If a corpse has been confirmed positive for Covid-19, the funeral procedure must be carried out according to the Covid-19 procedure. Swab tests are mandatory so that the patient's family can find out positive or negative of Covid-19 infection, so there will be no doubt from the family to the hospital in the process of handling the patient. The requirements for taking the corpse of the Covid-19 PDP are the existence of a Polymerase Chain Reaction (PCR) examination certificate which is declared negative. After being declared dead, the family of the corpse has to wait around 4-5 hours to be examined first ${ }^{5}$.

The thing that must be considered in handling the Covid-19 PDP corpse is that if the corpse in question has been confirmed to be positive for Covid-19, then the funeral process must be carried out according to the Covid-19 procedure. However, if the corpse is proven negative for Covid-19, then the funeral process can be carried out in accordance with the Sharia or the provisions of their respective religions. However, there is an appeal to the family so that the burial and funeral processes continue to apply health protocols, from wearing masks to maintaining distance.

This procedure is stipulated as a guideline for handling the corpses of infectious patients in health services, preventing transmission of disease from the corpse to the mortuary clerk and preventing disease transmission from the corpse to the environment and visitors. The scope of the protocol, starting from the room, transferring to the mortuary, managing the corpse in the mortuary, handing over to the family to corpse management. Based on Law ${ }^{6}$

1. Law Number 24 of 2007 concerning Disaster Management

2. Presidential Regulation Number 17 of 2018 Organization of disaster management in certain circumstances

3. Decree of the Head of BNPB Number 9.A. of 2020 concerning Determination of the Status of Certain Circumstances of Disaster Emergencies for Disease Outbreaks due to Corona Virus in Indonesia

4. Decree of the Head of BNPB Number 13.A of 2020 concerning the Extension of the Status of Certain Circumstances of Disaster Emergencies for Disaster Outbreaks due to Corona Virus in Indonesia

5. MUI Fatwa Number 14 of 2020 concerning the Organization of worship in a situation of the Covid 19 outbreak.

6. MUI fatwa Number 18 of 2020 concerning guidelines for the corpse management (tajhiz al-jana'iz) of Muslims who died because of Covid-19.

7. Guidelines for prevention and control of Covid-19 of the Ministry of Health

\section{Criminal Law}

The term of criminal law is a translation of the Dutch term strafrecht, Straf means criminal, and recht means law. The definition of criminal law has been stated by many legal scholars, including Soedarto, which defined that: Criminal law contains legal rules that bind to actions that fulfill certain conditions of a result in the 
form of a crime.

Furthermore, Moeljatno explained that from the definition of criminal law as mentioned above, then what is referred to in 1st) is to recognize a "criminal act". While what is mentioned in the 2nd) is about "criminal liability" (criminal liability or criminal responsibility). What is mentioned in the 1 st and 2 nd) is the "substantive criminal law", because it concerns the contents of the criminal law itself. What is mentioned in the $3 \mathrm{rd}$ ) is the method or procedure for prosecuting people suspected of having committed a criminal act, therefore the criminal procedure law. Usually what is referred to as criminal law is substantive criminal law.

Criminal law based on the material it regulates consists of substantive criminal law and formal criminal law. Tirtamidjaja explained substantive criminal law and formal criminal law as follows:

a. Substantive criminal law is a collection of legal rules that determine criminal offenses, establish conditions for criminal offenders to be punished, indicates a person is punishable and can establish a penalty for a criminal offense.

b. Formal criminal law is a collection of legal rules that regulate how to defend substantive criminal law against offenses committed by certain people, or in other words regulate how substantive criminal law is realized so as to obtain a judge's decision and regulate how to implement a judge's decision.

The characteristic of law is force accompanied by threats and sanctions. But the law is not forced to justify wrong issues, or to force those who are not hold the position and not have money. In order for the rules of social life to be strictly obeyed so that they become the rule of law, then these social regulations must be equipped with an element of force. Thus, the law has the nature of regulating and forcing everyone to obey the order in society and to provide strict sanctions (in the form of punishment) for anyone who does not want to comply?

In Law Number 4 of 1984, article 5 paragraph (1) Efforts to countermeasures the outbreak include: a) Epidemiological investigation;

b) Examination, treatment, care and isolation of patients, including quarantine measures;

c) Prevention and immunization;

d) Destruction of disease causes;

e) Handling of corpse due to the outbreak;

f) Counseling to the community;

g) Other countermeasures.

One of the regulations that has been made is the DKI Regional Regulation regarding Corona. This regulation covers a broad range of issues ranging from regulating the rights and obligations as well as responsibilities of the government to the implementation of Large-Scale Social Restrictions (PSBB). Meanwhile, imprisonment sanctions for offenders of the DKI Corona Regional Regulation have been removed and replaced with fines such as fines for forcibly taking the corpse of Covid-19. Based on Article 31 paragraph 1 of the Regional Regulation, the act of forcibly taking the corpse of Covid-19 is also classified as a criminal act. However, if the taking the corpse of Covid-19 is accompanied by threats, then the value of the fine will increase to IDR 7.5 million $^{8}$.

The Police of the Republic of Indonesia have stated that the forcibly taking the corpses that have tested positive for Covid-19 is an act of violating the applicable statutory regulations because it will cause harm to various parties and this is also a criminal act.

Many parties have become suspects by the Indonesian National Police. The Police of the Republic of Indonesia have also compiled regulations or instructions to resolve cases of forcibly taking the corpse of Covid-19 patients, namely by issuing a telegram letter from the Chief of the Indonesian National Police Number ST/1618/VI/ Ops.2/2020. Firm action is needed against those who are still forcibly taking the corpse of Covid-19 patients. So it also requires the involvement of religious leaders, the community, humanists, sociologists, anthropologists, to communicate and provide understanding to the community so that there should be no more cases of 
forcibly taking the corpse of Covid-19.

With the telegram letter from the Chief of the Indonesian National Police, if there are still parties who take the corpse of a Covid-19 PDP patient forcibly, they can be subject to criminal sanctions. The basis is Article 5 of Law Number 4 of 1984 concerning Infectious Disease Outbreaks with the threat of one year in prison or a fine of up to IDR 100,000,000 (One Hundred Million Rupiah) as regulated in Article 93 of Law Number 6 of 2018 concerning Health Quarantine. In addition, parties who forcibly taking the corps of PDP patients with Covid-19 may also be subject to layered articles, namely Article 211 of the Criminal Code in conjunction with Article 335 of the Criminal Code in conjunction with Article 336 of the Criminal Code in conjunction with Article 93 of Law Number 6 of 2018, with a penalty of up to 7 (seven) years.

As for article 211 of the Criminal Code states "Whoever with violence or threat of violence forces an official to carry out an official act or not to carry out an act of lawful position, shall be punished by a maximum imprisonment of four years". And article 335 of the Criminal Code

(1) Punished with a maximum imprisonment of one year or a maximum fine of five hundred rupiahs:

6. Whoever against the law forces other people to do, not do or allow something, by using violence, any other act or unpleasant treatment, both to that person and others.

7. Whoever forces other people to do, not do or allow something under the threat of defamation or defamation in writing

(2) In as formulated in point 2, a crime is only prosecuted upon the complaint of the person affected.

Article 14 of Law 4/1984 has threatened that:

1. Whoever obstructs deliberately the implementation of the outbreak countermeasures as regulated in this Law, shall be punished with a maximum imprisonment of 1 (one) year and/or a maximum fine of IDR 1,000,000 (one million rupiah).
2. Whoever due to his/her negligence obstructs the implementation of outbreak countermeasures as regulated in this Law, shall be punished with imprisonment for a maximum of 6 (six) months and/or a maximum fine of IDR 500,000 (five hundred thousand rupiah).

3. Criminal acts as intended in paragraph (1) are crimes and criminal acts as referred to in paragraph (2) are violations.

In addition, Article 93 of Law 6/2018 on Health Quarantine states that:

Every person who does not comply with the organization of Health Quarantine as referred to in Article 9 paragraph (1) and/or obstructs the organization of Health Quarantine so as to cause a Public Health Emergency will be sentenced to a maximum imprisonment of up to 1 (one) year and/or a maximum fine of IDR 100,000,000 (one hundred million rupiah).

Whoever by force or threats of violence against a civil servant who performs his/her legitimate job, or against a person who while helping that civil servant because of his/her obligations under the law or at the request of the civil servant, is punished for resistance, with a maximum imprisonment of one year and four months or a maximum fine of IDR 4,500.

An action that is prohibited by law which, if violated, will be subject to criminal sanctions. In statutory regulations, there are many terms used where these terms have the same meaning as criminal acts, including criminal events, punishable acts, offenses, criminal offenses, and others. Forcibly taking the corpse is an act against the law. Actions prohibited by law which, if violated, will receive sanctions.

Forcibly taking the corpse of Suspect/Probable Covid-19 patients often occurs, one of which is for reasons of families who are afraid to be considered as people who have the potential to spread the Covid-19 outbreak in neighborhoods. In addition, the family of a corpse suspected/probably Covid-19 patients if they are proven positive for Covid-19, then the funeral process will be carried out in accordance with the Covid-19 countermeasures protocol. This causes the surrounding 
community or neighbors to know that the patient is a Covid-19 patient. Communities who do not understand information about Covid-19 transmission will try to refuse the funeral because the funeral was carried out in that community environment. The community is afraid if the corpse of a Covid-19 patient can transmit the Covid-19 outbreak in their environment even though the corpse has been managed according to the Covid-19 protocol.

As for the content of Article 178 of the Criminal Code, namely: "Whoever blocks deliberately or obstructs the entrance or transportation of a corpse to the grave is permitted, shall be punished by a maximum imprisonment of one month and two weeks or a maximum fine of one thousand eight hundred rupiahs". This article is under the chapter on crimes against public order. This formula has its equivalent in Nederland Wetboek van Strafrecht, namely Article 148. This criminal threat is addressed (normaddressat) to "whoever", or "anyone". The core parts of the offense were "deliberately", "blocking or obstructing", and "permitted entry or transport of the corpse to the grave".

This action has to be done deliberately to 'block', meaning to obstruct, so that the carrying of the corpse cannot take place (verhideren). "Troubling" means disturbing, so that although the carrying of the corpse can take place, it is with difficulty (belemmeren). The carrying of a corpse should not be prohibited, which means that carrying is proper, has been given permission by the government officials, not illegal burial ${ }^{9}$.

\section{Conclusion}

Forcibly taking the corpse of Suspect/Probable Covid-19 patient if not subject to sanctions, there will be not deterrent effect for preperator but will also have a social impact. If the corpse of Suspect/Probable Covid-19 patient is not performed corpse management in accordance with the Covid-19 protocol, this will lead to the potential for Covid-19 transmission to those who mourn at the funeral home and the person who bathes the corpse. Without realizing it, the corpse management and funeral for the corpse created a new cluster of Covid-19. The rapid and more widespread spread of Covid-19 has had a social impact in the form of increasingly stringent
PSBB (Large-Scale Social Restrictions) regulations, so that economic activity is hampered and there are more open unemployment.

Forcibly taking the corpse of Suspect/Probable Covid-19 patients often occurs, one of which is for reasons of families who are afraid to be considered as people who have the potential to spread the Covid-19 outbreak in neighborhoods. In addition, the family of a suspected/probable Covid-19 patient if it is proven positive for Covid-19, then a funeral process will be carried out in accordance with the Covid-19 countermeasures protocol. This causes the surrounding community or neighbors to know that the patient is a Covid-19 patient. Communities who do not understand information about Covid-19 transmission will try to refuse the funeral because the funeral was carried out in that community environment. The community is afraid that the corpse of a Covid-19 patient can transmit the Covid-19 outbreak in their environment even though the corpse has been performed a corpse management according to the Covid-19 protocol.

Obstruct officers from conducting official funeral is legally punishable. Law enforcement officials can use Article 178 of the Criminal Code. The act of forcibly taking the corpse of Suspect/Probable Covid-19 patients by parties who do not have the authority is an act against the law. This is contrary to the procedures for handling the corpse of Covid-19. This can be seen in each of the articles in the existing, namely the 1945 Constitution, Law Number 4 of 1984 article 5 and article 214 Criminal Code in conjunction with Article 211 Criminal Code, Article 335 Criminal Code in conjunction with Article 336 Criminal Code in conjunction with Article 93 Criminal Code Law Number 6/2018.

Ethical Clearance : Nil

Conflict of Interest : Nil

Source of Funding : Self Founding

Acknowledgement : Nil

\section{References}

1. Director General for Controlling and Prevention of Infectious Diseases. Pedoman Pencegahan dan 
Pengendalian Corona Virus Disease (COVID-19). 5th Rev. Jakarta: Ministry Of Health; 2020.

2. Batang H. Handling of the bodies of Covid-19 patients. 2020 (Cited 1 Nov 2020). Available from: https://www.rsudbatangkab.com/index.php/ informasi/artikel/112-penanganan-jenazah-pasiencovid-19.

3. Arifin DA. Kajian Yuridis Tanggung Jawab Perdata Rumah Sakit Akibat Kelalaian Dalam Pelayanan Kesehatan. 2nd Vol. J Idea Hukum; 2016.

4. Yazid F. Penerapan Sanksi Pidana terhadap Pengambilan Paksa Jenasah Pasien Covid-19 di Indonesia. 6th Vol. J Belo; 2020.

5. Haetharia S. Aspek Tanggung Jawab Hukum Rumah Sakit Terhadap Pelayanan Medis. 1st Vol. Lex etSoc; 2013.
6. Putra RS. Pedoman Pemulasaran Dan Penguburan Jenazah Akibat Covid-19 Di Masyarakat. Jakarta: Ministry Of Health; 2020.

7. Suharto, Efendi J. Panduan Praktis Bila Menghadapi Perkara Pidana Mulai Proses Penyelidikan Sampai Persidangan. Jakarta: Prestasi Pustaka; 2010.

8. Forcibly take the body of Covid-19, get ready to be fined Rp. 5 million. 2020 (Cited 5 Dec 2020). Available from: https://jakarta.suara.com/ $\mathrm{read} / 2020 / 10 / 19 / 191522 /$ ambil-paksa-jenazahcovid-19-siap-siap-didenda-rp-5-juta.

9. Soesilo R. Kitab Undang-Undang Hukum Pidana (KUHP) and the Comments are Complete Article by Article. Bogor: Politea; 1994. 